\title{
EMPLOYMENT OPPORTUNITIES WITH PROMOTING WASTE MANAGEMENT IN
} INDIA

\author{
Shubham Sharma ${ }^{1,2 *}$, Shivam Upadhyay ${ }^{3}$, Bharat Singh ${ }^{4}$ \\ ${ }^{1}$ Electrical EPC Business, Jakson Limited, India \\ 2 Vidya Alumni Society, Vidya College of Engineering, Vidya Knowledge Park, India \\ ${ }^{3}$ Powergen Business, Jakson Limited, India \\ ${ }^{4}$ Human Resource \& Administration Department, Jakson Limited, India \\ ${ }^{*}$ Corresponding Author Email: sshubham.1711@gmail.com; Tel.: +91-9818703336, +91-9536800815
}

This is an open access article distributed under the Creative Commons Attribution License, which permits unrestricted use, distribution, and reproduction in any medium, provided the original work is properly cited

\section{ARTICLE DETAILS}

\section{Article History:}

Received 04 January 2019 Accepted 18 February 2019 Available Online 25 February 2019

\section{ABSTRACT}

Being a developing nation, India is undergoing several issues in its journey from being developing to developed. Out of these issues' proper management of waste and unemployment are two major hurdles in its journey of growth and prosperity. The Press Information Bureau states that the approx. 62 million tonnes waste is generated annually in India \& the count of unemployed people in India is reduced to 44.85 Million from 48.26 Million if we compare the data of 2016 \& 2014. But this decrease in value of unemployed people is still less to achieve the status of developed and prosperous nation. Hence the focus of the study mentioned in this paper is to convert the problem of waste management into a fruitful solution of providing employment opportunities to skilled, un-skilled and semi-skilled people which will lead to clear and hygienic atmosphere. Presently India is the sixth-largest economy of the world by nominal GDP and in terms of purchasing power parity (PPP) it is the Third Largest. India is playing a vital role in the world's economy but the first question which comes in our mind after knowing this, is "What is the contribution status of India in terms of world's environmental concern? "As per the data provided by authorities such as Ministry of New and Renewable Energy and Ministry of Housing and Urban Affairs, Government of India, India is producing around 60-65 metric tonnes waste per year basis. But our main concern should be, that we are still not able to Reutilize more than $20 \%$ of the total waste generated per year. Challenges are very common and basic like unsegregated waste, unsystematic waste collection, inappropriate recycling and unscientific disposal and so on. India has the capacity of generating $2.54 \mathrm{GW}$ electricity by using Waste to Energy process. In coming few years India's waste management market has the potential to give the additional support to the nation's economy with the worth of 14 billion USD with the rapid annual growth rate of $7 \%$. Thus, we need to improve all related challenges and should focus on making our nation clean, healthy and prosperous in terms of economy and environment.

\section{KEYWORDS}

GD, PPP, MNRE, MoUD, RE-Utilize, Waste-to-Energy

\section{INTRODUCTION}

The solution of any problem lies in the problem itself if the same is detected at an early or a mediocre stage. India is rich in several aspects, but several problems are deteriorating the prosperity index of the nation. Unemployment and Waste Management are the two such major concerns. By the below stated facts and study the concern is to create awareness about developing and creating employment opportunities in India for skilled and unskilled manpower by increasing the ways and techniques of proper waste management.

The increase in technology is leading to economic growth of India. This growth is directly proportional to Urbanization and population rise. Also, this rapid advancement results in increase in consumption of goods and services at a very fast rate. Due to this the waste generated in India is also boosted up to two times i.e. just double in last 1 decade [1]. As stated above the two major concerns are waste management and unemployment. Waste Management needs a very sharp attention these days if we talk about it in India. Proper Research and Development for making new innovations and developing more efficient techniques is the need of the era. This development will directly lead to requirement of manpower, specifically, skilled ones and the outcome of these research projects will require both skilled and unskilled manpower at mass scale. In short Waste Generation can be used as a revolutionary segment to boost up the level of employment opportunities in India for both skilled and unskilled manpower.

Considering the mixed waste which includes the recyclable and nonrecyclable waste in total 62 million tonnes of waste is generated annually in India as per Press Information Bureau. Out of this waste only $60 \%$ of the waste is collected and out of this waste only $15 \%$ is properly processed or managed. The reason behind this is that we people are very fast in considering a thing as a waste as soon as it is of no use for us. We are very less concerned about Reuse of a product in any other way or in any other requirement. As a result, we do not focus majorly or aggressively on development of new and efficient waste management techniques. For example, there is a fully equipped and advanced waste management plant processing the waste of $100 \mathrm{Kms}$ area in its nearby periphery. By this paper the concern is that 10 plants at a distance of every $10 \mathrm{kms}$ should be installed which will lead to generation of employment to those who will construct that plant, work in that plant, research in that plant and other persons such as Engineers, Computer operators, scientist, accountants, marketing and business development managers, skilled and unskilled 
labor etc.

There should not be any doubt in saying that with rate of population increment and urbanization this data will count as 80 MTs per annum by year 2030. This amount of waste generation is clearly offering the business opportunities around of 20 billion USD. Thus, the present and upcoming authorities need to concern on this availability of data, which is showing that India can get the relief in term of unemployment rate of the country if the implementation of waste management and waste to energy conversion plants will set up in the series that at least every urban localities is having its own small or medium waste to energy conversion plan

\section{CLASSIFICATION OF WASTE}

According to the source of generation, impacts and properties waste can be classified as the mentioned below: -

Table 1: Classification of Waste [2]

\begin{tabular}{|c|c|}
\hline Residential & $\begin{array}{l}\text { - Food Wastes, paper, cardboard, } \\
\text { plastics, textiles, leather, yard wastes, } \\
\text { wood, glass, metals, ashes, e-wastes }\end{array}$ \\
\hline Industrial & $\begin{array}{l}\text { - Housekeeping wastes, packaging, } \\
\text { food wastes, construction and } \\
\text { demolition materials, hazardous } \\
\text { wastes, special wastes. }\end{array}$ \\
\hline Commercial & $\begin{array}{l}\text { - Paper, cardboard, plastics, wood, } \\
\text { food wastes, glass, metals, special } \\
\text { wastes, hazardous wastes, e-wastes. }\end{array}$ \\
\hline $\begin{array}{l}\text { Municipal } \\
\text { Services }\end{array}$ & $\begin{array}{l}\text { - } \quad \text { Street sweepings, landscape and tree } \\
\text { trimmings } \\
\text { - } \quad \text { General Wastes from Parks, beaches } \\
7 \text { other recreational areas, sludge. }\end{array}$ \\
\hline $\begin{array}{l}\text { Construction \& } \\
\text { Demolition }\end{array}$ & $\begin{array}{l}\text { - Wood, steel, concrete, dirt, bricks, } \\
\text { tiles }\end{array}$ \\
\hline Medical Wastes & $\begin{array}{l}\text { - Infectious wastes, hazardous wastes, } \\
\text { radioactive wastes from cancer } \\
\text { therapies, pharmaceutical waste. }\end{array}$ \\
\hline Agricultural & $\begin{array}{l}\text { - Spoiled food wastes, agricultural } \\
\text { wastes like rice husks, cotton stalks, } \\
\text { coconut shells, coffee waste, } \\
\text { hazardous wastes like pesticides, }\end{array}$ \\
\hline
\end{tabular}

Residential waste are those unusable products which are generated from or by day to day household activities. These wastes include peels of fruits and vegetables, polythene, wood products, paper, glass, clothing and textile materials, metal and steel related small products, etc. These wastes are usually come in the existence when the wastage of household entities take place. Thus, in the result of that, the wastage of their house come out to the streets and drains and after that, those waste materials reach up to the environmental entities and causes the disorder in their functioning.

Industrially generated wastes are usually one of those wastes which are produced as the ending materials of any industrial process of productivity. These types of wastes are called hazardous waste, i.e. those categories of wastes which can create very bad situation for mankind. Commercially generated wastes are usually those types of waste which is the resultant of a commercial firm which operates in the time duration of mainly from 9AM to 5PM, i.e. specifically office timing. It consists papers, cardboards, plastics, special waste, some form of hazardous waste, food waste, e- waste etc.

Municipally generated wastes are those categories of waste which are producing through the municipal bodies of any locality, it takes place due to weak management policy of the authorities. Such wastes in this domain are street sweepings, general wastes from parks, beaches, sludge etc. Construction and demolition based generated wastes, in any construction and demolition process there will come out some sort of eventual ending materials will remain there, these products are considered to be the waste of this domain. Ex: wood, steel, concrete, dirt, bricks and tiles etc.
Medical waste is that span range of generated waste till the date in which very dangerous waste produces which can create the death scenario for the bunch of people because the chemicals which theses wastes are containing with themselves as their property are very active to pollute all those environment entities through which the mankind is surviving on this plant. Ex; infectious waste, hazardous waste, radioactive waste etc. Agricultural wastes are generated by the agricultural activity of a specific locality. In this category the wastes are those one waste, which usually come in the existence when the food is spoiled in some or the other way, wastes like rice, husks, cotton stalks, coconut shells, coffee wastes usually count under umbrella of specific types of agricultural waste.

Eventually having this deep discussion of all these categorically defined wastes we got a conclusion that population and increasing goods demand due to that is playing a vital role in generation of waste but at the same time if we will treat the wastes in a proper manner regarding its collection, conversion and recycle then we do not think that generation of waste will remain as the major concern for environment as it is at present. And very clearly, we can do this also, we need to set up some effective policies regarding it and we need to ensure that the formulation and the implementation of all those rules are taking place which are proposed by the concern authorities

\section{GENERATION OF MUNICIPAL WASTE}

Population chart talks about the rapid increment in the number of India's population data and the outcome is clearly stating that this is an alarming situation not only for our country in fact it is also major issue for every single person who is living here. In year 2017-18, the population has been remarked with the number of around 1.3 billion this data was 1252 million in the year 2013-14 and in the year of session 2001 according to population census this population data was about of 1028 million. The reason behind telling this story of population increment is only because we want to draw a line for the other ones that the truth is population increment is happing almost in every country but the rate of happening this increment is not that high as we are having in the context of India, so the point is Why the waste generation is a major problem in India? It is a major issue because of rapid population increment, this factor is playing the role as main contributor for this cause.

\subsection{Rapid Increase of mega cities in India}

Due to technological advancement, globalization of not only in terms of economy in fact the cultural barriers are also breaking thus in the result of all these big things which are happening, a new phenomenon of megacities is came out with the concept that becoming economically strong is not enough, a nation has to be that much stronger in term of infrastructure also. In order to the discussion about the possibilities of waste generation in the Indian cities are likely to be depends upon the population of that specific area. Since the municipal waste generation is completely depends upon the consumption of the goods by population and their remaining residuals [3].

\section{Class IA Cities}

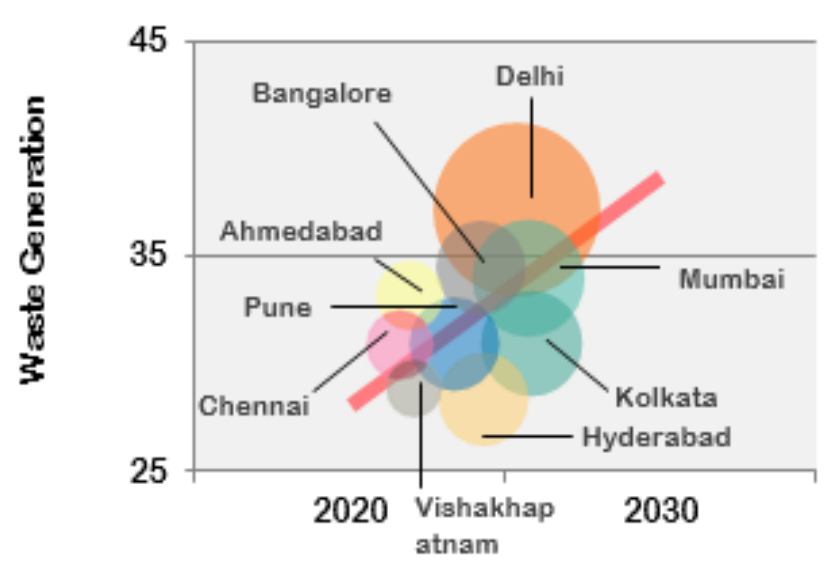

Figure 1: Year wise Waste generation in Class IA Cities 


\section{Class IB Cities}

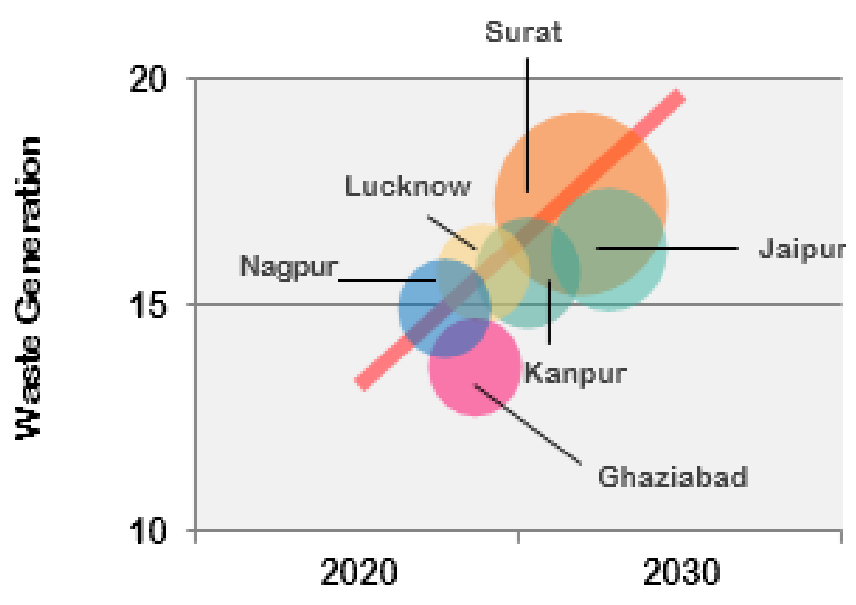

Figure 2: Year wise Waste generation in Class IB Cities

\section{Class IC Cities}

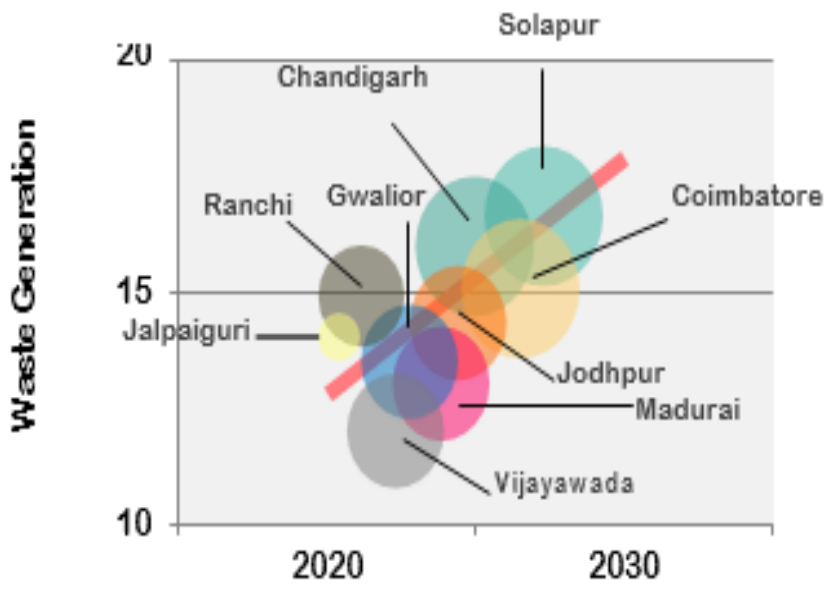

Figure 3: Year wise Waste generation in Class IC Cities

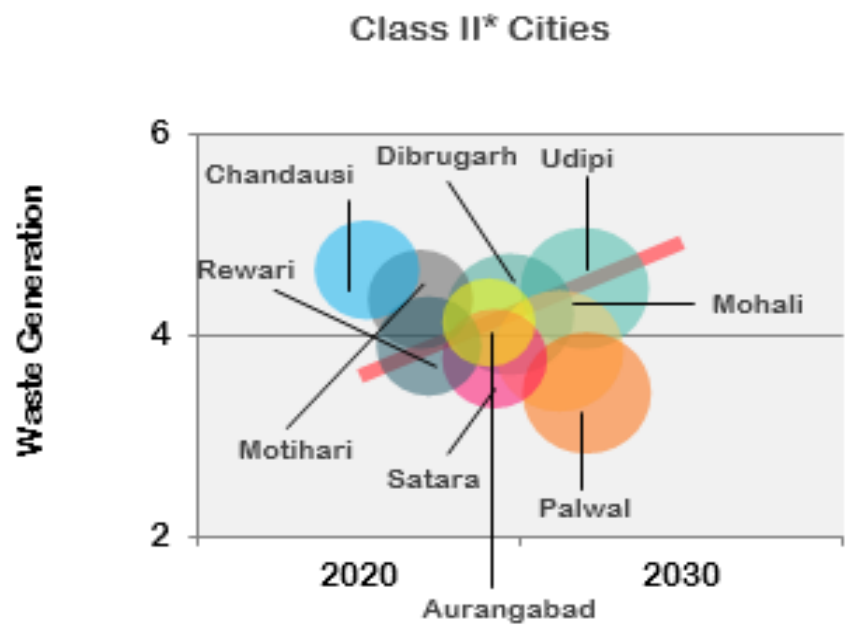

Figure 4: Year wise Waste generation in Class II Cities [3]

Through the above mention diagrams, it is represented that we are using the capacity of waste generation according to different cities on the basis of their population index. This description is analyzed from the national authorities related to the waste management system and capacity of waste generation from year 2020 to 2030 . It is assumed that if the way of producing waste will continue with the same sprit than there is no doubt that the data will be as approximately similar the diagram is showing.

Class IA cities are those cities which consist the population above 5 million. Such as Delhi, Mumbai, Kolkata, Pune, Bangalore, Hyderabad, Ahmedabad Chennai, Vishakhapatnam. According to the population data of these cities we can say the amount of waste generation is majorly depends upon the urbanization of the nation. In India the rapid urbanization is the main reason of dysfunctional waste management system, becoming urbanized is not an issue but giving less attention towards the implementation of a proper controlling and treating process is a major problem. We really need to focus on it, that which methodology will help us to recur from this future wrong impacting possibilities.

Class IB cities, are those cities which consist the population between 1 million to 5 million. Such as Surat, Jaipur, Kanpur, Lucknow, Ghaziabad, Nagpur. These cities are the contributor in waste generation. Class IC cities are those cities which consist the population between 0.1 million to 1 million. Such as Chandigarh, Sholapur, Coimbatore, Jodhpur, Madurai, Gwalior, Vijayawada, Ranchi, Jalpaiguri. These cities do not have very high population but sometimes the miss management of waste can be the cause of high waste management. Class II* cities, are specifically those number cities which are recently getting empowered and becoming urbanized.

Since the population is not that much high or we can say it is less, in comparison to other major cities thus the failure of waste management in these cities are surely based on the lack of information regarding the proper collection and treatment of the generated waste.

\section{PROCESS FOR TREATMENT OF WASTE}

Table 2: Process for Treatment of Waste

\begin{tabular}{|l|l|l|}
\hline \multicolumn{3}{|c|}{ Concept- Thermochemical } \\
\hline \multicolumn{1}{|c|}{ Process } & Energy Carrier & Application \\
\hline Incineration & Fuel Gas/ Steam & Heat \\
\hline $\begin{array}{l}\text { Conventional/ } \\
\text { Plasma Gasification }\end{array}$ & Syngas & Electricity \\
\hline Pyrolysis & Syngas \& Bio Oil & Hydrogen \\
\hline Biomethanation & Biogas & Chemicals \\
\hline Fermentation & Ethanol & Transport Fuel \\
\hline \begin{tabular}{l} 
Concept- Mechanical \\
\hline $\begin{array}{l}\text { Compressing, } \\
\text { pelletizing }\end{array}$
\end{tabular} & $\begin{array}{l}\text { Refused Derived } \\
\text { Fuel }\end{array}$ & $\begin{array}{l}\text { Feed Stock for Thermal } \\
\text { Process }\end{array}$ \\
\hline
\end{tabular}

This process classification of waste treatment is very clear about its fundamental concepts, using process, energy carriers and applications [2]. Wastes are classified in three different categories on the basis of their fundamental concepts these are thermo electrical, biochemical, mechanical. Thermo chemical consists three different processes of waste treatment are incineration, conventional/plasma gasification, pyrolysis. where all these three types consist the different energy carriers like flue gas/steam is the carrier for incineration process while the other two have syngas and syngas \& bio-oil respectively. These processes are the application of different fields which are described in the diagram.

Biochemical concept consists two different processes of waste handling are biomethanation and fermentation. Energy carriers for these process are biogas and ethanol respectively while the diagram is clearly telling about the application of these processes. Mechanically concentrated waste handling concept consists a single process which is called crushing, compressing, pelletizing, And the energy carrier for this process is purely refuse derive fuel. Application of this process is hugely implanted in the feed stock for thermal process. 


\section{GOVERNMENT ACTION FOR POSITIVE TREATMENT}

As per Solid Waste Management Rules 2016, it is the duty and responsibility of local authorities to "setup material recovery facilities or secondary storage facilities with sufficient space for sorting of recyclable materials to enable informal or authorized waste pickers and waste collectors to separate recyclables from the waste and provide easy access to waste pickers and recyclers for collection of segregated recyclable waste such as paper, plastic, metal, glass, textile from the source of generation or from material recovery facilities". In addition, under Swachh Bharat Mission-Urban, a guide titled "An Inclusive Swachh Bharat through the integration of the Informal Sector: A Step by Step Guide" has been published to help the Urban Local Bodies \& States to integrate informal waste pickers to promote reuse/ recycling of solid wastes. For the recycling and reuse of Construction \& Demolition Waste, the Bureau of Indian Standards (BIS) has amended/revised the IS 383 - Specification for Coarse and Fine aggregates, enabling the use of recycled aggregates in construction activities [4].

To generate power by utilizing municipal solid waste, industrial waste, agricultural waste and urban waste, the central financial assistance (CFA) is providing by the ministry of new and renewable energy (MNRE) government of India for setting up the waste to energy plants at wide level. In addition, the Swachh Bharat Mission under the Ministry of Housing and Urban Affairs also provides central assistance of $35 \%$ of the total project cost to all statutory cities/ towns as per the guidelines for Solid Waste Processing including waste to energy projects. No specific suggestion has been received in this regard by the Ministry of Housing and Urban Affairs as well as MNRE on waste to energy plants from State Governments. At present, six waste-to-energy plants using Municipal Solid Waste (MSW) with cumulative installed capacity of $65.75 \mathrm{MW}$ are in operation in the country [5].

\section{STATUS OF WASTE MANAGEMENT IN INDIA}

It has been stated by the number of the national and international agencies that India's waste management market is really having the opportunity to grow up to its significant level. Thus, in same context, if we consider the data of information which they have been already stated then by the year 2025 the size of waste management market in India is assumed to be worth of USD 14 Billion with 7\% of annual growth. Total W2E potentia of India $2.54 \mathrm{GW}$. $2.43 \mathrm{GW}$ Existing W2E opportunity in India. Close to $5 \%$ of the total W2E Potential in India has been harnessed as on 2017 [3].

States such as Maharashtra, Uttar Pradesh, West Bengal, Andhra Pradesh \& Delhi holds the major chunk opportunity of the existing potential. According to their waste generation capacity the discrimination is clearly specify from municipal to industrial waste management and conversion from waste to electricity [3]. States like Uttar Pradesh, West Bengal, Maharashtra, Tamil Nadu and Andhra Pradesh these are focused towards the major possibility of municipal waste management due to their growing population. Population is the vital role player in the enhancement of municipal waste generation quantity. Increasing population is helping to raise the level of living standard because now there are lots of minds are working together to find out the better and then best way of living a life which should be facilitated with all the desired amenities.

In the same order of controlling and treating the generated waste now we will discuss about the industrial waste scenario and in this context, we see that the states which are emerging daily in terms of industrial aspects are such as Rajasthan, Gujarat, Madhya Pradesh, Telangana And Chhattisgarh. These states are the example of exceptionally industrialized states recognized not only in India in fact they have worldwide popularity [6] With contain the crown of most rapid emerged states if the management of generated waste is not in the proper manner than this will be more shame full for us rather feeling proud that these states are our nation's territories.

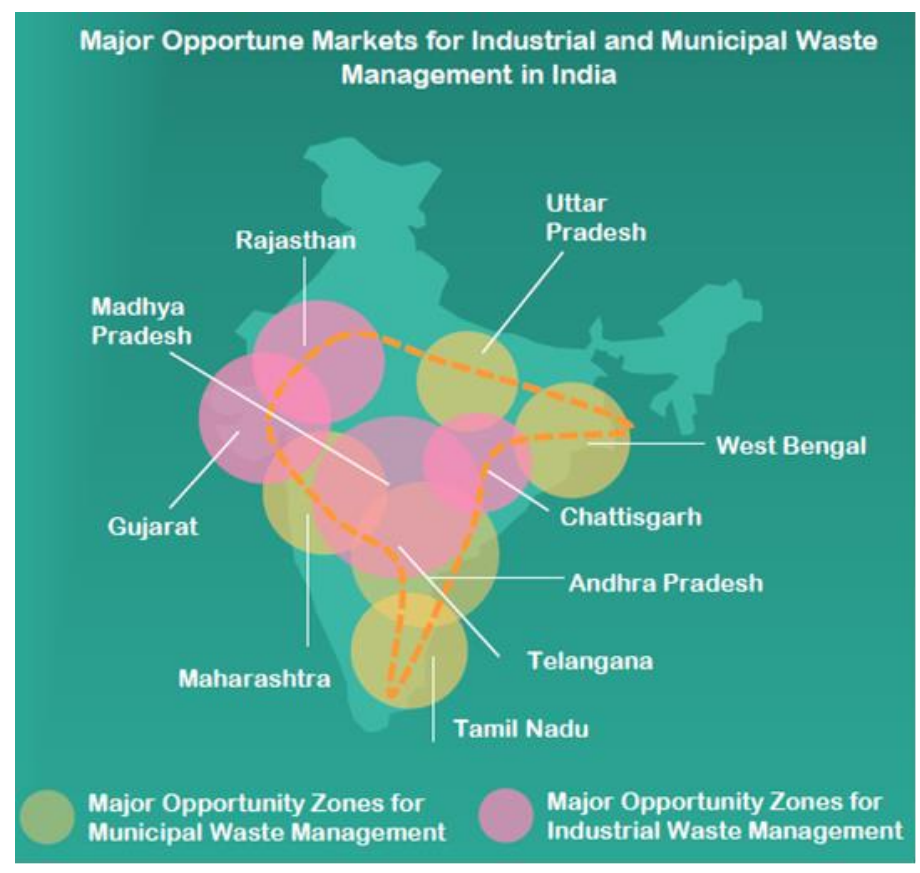

Figure 5: Major Opportune Markets for Industrial and Municipal Waste Management in India

Industrial wastes are such that they definitely can use as the prime mover for other technical activity operation at the same time some of the waste which are generating as the residual of some big industrial plant, they can also generate energy or can help to do it in one or other form of catalyst.

Management and treatment of specifically these industrial wastes are very essential due to their very effective hazardous chemical properties [7]. In the same context municipal waste management and treatment for energy extraction is required too, because with the time consumption municipal wastes also converts into form of some dangerous opponent which can be the creator of blizzard situations for living human beings and environment.

Becoming the super power at the international forums should not be that single achievement which can make us satisfy that yes, we have become the leading economy in this world. Our main concern should be that, are we able to provide the maximum employment to all those young and upcoming new generation of this country? And the answer will be in the negative form [8]. So why the authorities are not working to search and create some new policies and regulation through which they will become to ensure that maximum educated youth of this country will secure their employment right.

\section{EMPLOYMENT THROUGH WASTE TO ENERGY IMPLEMENTATION}

India's urban waste management activities are basically turning into the sustainable employment opportunities for those class of people who are basically at the bottom in this series, but they are actually playing an important role for this process. According to the sources, only 5 municipal solid waste (MSW) to energy generating plants are there with a cumulative installed capacity of 66.5 MW are currently under on trial run purposes based or operational in the country [1]. 
Table 3: WTE in Indian Cities

\begin{tabular}{|l|l|l|l|}
\hline S. No. & \multicolumn{1}{|l|}{ State } & $\begin{array}{l}\text { Name of the } \\
\text { city/ Town }\end{array}$ & Capacity (MW) \\
\hline 1. & Maharashtra & Sholapur & 3.0 \\
\hline 2. & Delhi & Okhla & 12.0 \\
\hline 3. & Delhi & Ghazipur & 16.0 \\
\hline 4. & Delhi & Narela Bhawan & 24.0 \\
\hline 5. & $\begin{array}{l}\text { Madhya } \\
\text { Pradesh }\end{array}$ & Jabalpur & 11.5 \\
\hline & Total & & \\
\hline
\end{tabular}

Waste management and waste to energy conversion plants and policies regarding this can be implemented on micro level too. Mean by the term micro level is like we are talking about giving the authorities, providing knowledge of advance technology and promoting the local bodies for their achievement, implementation, creating job opportunities and eventually creating and making the nation a better place for mankind, where the pollution will be negligible, green and clear energy will be offer to us and we make sure that our irresponsible acts are not harming the environment of the surroundings. Under Swachh Bharat Mission (SBM) the ministry of urban development has been received almost 53 proposals from 22 states with the capacity of electricity generation potential of $405.3 \mathrm{MW}$ [9]. Some of them are in the stage of construction and few of them are in stage of tender submission.

Table 4: Proposed WTE in Indian States [1]

\begin{tabular}{|c|c|c|c|}
\hline S.No. & State & $\begin{array}{l}\text { No of } \\
\text { Plants }\end{array}$ & $\begin{array}{l}\text { Total Proposed } \\
\text { Capacity } \\
\text { (MW) }\end{array}$ \\
\hline 1 & Andhra Pradesh & 11 & 85 \\
\hline 2 & Assam & 1 & 5 \\
\hline 3 & Bihar & 1 & 12 \\
\hline 4 & Chhattisgarh & 2 & 10 \\
\hline 5 & Delhi & 1 & 1.6 \\
\hline 6 & Gujarat & 3 & 30.5 \\
\hline 7 & Haryana & 3 & 18.5 \\
\hline 8 & Himachal Pradesh & 1 & 1.7 \\
\hline 9 & $\mathrm{~J} \& \mathrm{~K}$ & 1 & 6.5 \\
\hline 10 & Jharkhand & 2 & 23 \\
\hline 11 & Karnataka & 2 & 20 \\
\hline 12 & Kerala & 1 & 10 \\
\hline 13 & Madhya Pradesh & 5 & 32 \\
\hline 14 & Maharashtra & 3 & 28.5 \\
\hline 15 & Manipur & 1 & 1 \\
\hline 16 & Odisha & 1 & 11.5 \\
\hline 17 & Punjab & 2 & 16 \\
\hline 18 & Rajasthan & 3 & 26 \\
\hline 19 & Tamil Nadu & 1 & 8 \\
\hline 20 & Telangana & 1 & 11 \\
\hline 21 & West Bengal & 1 & 22.5 \\
\hline \multirow[t]{2}{*}{22} & $\begin{array}{l}\text { Uttar } \\
\text { Pradesh }\end{array}$ & 5 & 25 \\
\hline & Total & 53 & 405.3 \\
\hline
\end{tabular}

If we consider the statements which has been already released by many of the international organizations in the order to explain the possibilities of creating employment in a very huge amount from waste to energy power plants, we really can do this. As far as we are concern about it, we must say that if we really want to give a better living standard to our citizens then we definitely need to work towards this [10]. Because the implementation and promotion of this thought is not only for fulfilling the desire of creating employment but this is also very helpful to securing our nature from the harm causing by the pollution on the daily basis.

\section{ACHIEVEMENT OF EMPLOYMENT THROUGH WASTE MANAGEMENT}

As stated above approximately 62 million tonnes of waste is generated annually. Out of this waste only $60 \%$ is collected and around $15 \%$ is processed. Hence the question arises is Where is the remaining waste? The remaining quantity of waste is lying unsegregated and without any proper management which will cause loss to hygiene and scenic beauty of environment. If we increase the waste management plants in India, it will create opportunities of employment to several unemployed, skilled, semiskilled and un-skilled manpower of the country in following ways: -

a. Awareness must be created for proper disposal of waste. For this local guides and local mentors are needed for door to door campaign regarding promotion of benefits of proper waste dumping.

b. Manpower is required to collect the waste from homes or from specific dumping points.

c. Despite of large waste management plants at larger distance, waste management plants of small capacity at less distance must be installed. This will lead to increase in employment opportunity for local people as the installation of new plant requires design person, Civil, Mechanical, Electrical and Software Engineers, Clerical Staff, Office boys and other relevant staff.

d. Industrial Research \& Development centers must be installed at waste management plant so that they can explore new products from the waste processed at the plant. This will create opportunity for Scientists, Research Fellows/ Scholars and Chemical Engineers.

e. So, as the count of plants increases there will be a chance of increase in opportunity of employment for the following: -

$\begin{array}{ll}\text { i. } & \text { Human Resource Person } \\ \text { ii. } & \text { Research \& Development Person } \\ \text { iii. } & \text { Engineers } \\ \text { iv. } & \text { Executive Staff } \\ \text { v. } & \text { Labours } \\ \text { vi. } & \text { Entrepreneurs } \\ \text { vii. } & \text { Sales \& Marketing person, etc. }\end{array}$

\section{CONCLUSION}

Employment is the fundamental humanitarian right which should ensure by the authorities, are they possibly able to give the job opportunities or are they promoting the young entrepreneurs to create jobs in the sustainable manner? The answer is, they are not able to fulfill this statement. Thus, according to the world-wide spread wave of clean energy policies implementation. India should also make sure that, we as the land of nature diversity, firstly we need to ensure that environment safety is our main focused. Our second concern should be that the unemployment rate will decrease as the increment in the job opportunities creation in the nation for supporting to real growth to our economy. So basically, it must ensure that the maximum quantity of resource extraction is taking place from the generated waste by economical and sustainable feasibility. The secondary but more important than extracting the resources from waste is the disposal of the residual waste, so maximum resources extraction is definitely our first concern but there should be safe disposal of residual waste also. Safe disposal becomes very easy when we involve the best developed technology with it. Due to poor waste policy, lack of trained people and implementing the best waste technology, thus continuously this nation will face so many issues related to public health and environment concern.

Waste $\rightarrow$ Waste Management $\rightarrow$ Waste Management Techniques $\rightarrow$ Infra Growth $\rightarrow$ Manpower Requirement $\rightarrow$ Manpower Requisition $\rightarrow$ Manpower Recruitment of both skilled and unskilled people $\rightarrow$ Reduction in Unemployment $\rightarrow$ Rise in per capita income $\rightarrow$ Rise in GDP $\rightarrow$ leads to a better and economically prosperous India.

\section{ACKNOWLEDGEMENT}

The authors want to acknowledge the support and cooperation of M/s Jakson Limited, India \& Vidya Knowledge Park, Meerut, India in the course of this work. Special thanks to Dr. R.C. Singh, Sharda University, India, Dr. R.K. Chechi, Dr. Dinesh Kumar Sharma, Dr. Rajendra Kumar, Astt. Prof. Saurabh Sharma from Vidya Knowledge Park \& Dr. Aditya Gautam, Shri Ram Group of Institutions, Muzaffarnagar, India. 


\section{REFERENCES}

[1] Pandey, K.K., Kalyani, K.A. 2013. Waste to energy status in India: A short review. Renewable and Sustainable Energy Reviews, 31, 113-120

[2] R\&D of IOCL. 2017. 8th world renewable energy technology congress \& expo.

[3] Enincon Consulting LLP. 2018. Waste to Energy and Waste Management Market in India - 2018 (C) Enincon Consulting LLP.

[4] Singh, S.R.K. 2018. Lok Sabha Unstarred Question No. 2974 for 04/01/2018 regarding "Generation of Solid Waste". The Minister of State For Power And New \& Renewable Energy.

[5] Government of India ministry of new and renewable energy, small hydropower programs; [www.mnre.gov.in].
[6] Kothari, R., Kumar, V., Panwar, N.L. 2014. Municipal Solid -Waste Management strategies for Renewable Energy Options. Sustainable Bioenergy Production.

[7] Ahsan, N. 1999. Solid waste management plan for Indian megacities. Indian Journal of Environmental Protection, 19 (2), 90-95.

[8] Singh, R.P., Tyagi, V. 2011. An overview for exploring the possibilities of energy generation from municipal solid waste in Indian scenario. Renewable and Sustainable Energy Reviews, 15 (9), 4797-4808.

[9] Outlook web bureau. 2018. Jobs employment/unemployment, youth' 5 April.

[10] https://tradingeconomics.com/india/unemployed-persons accessed on 12th day of December 2018.

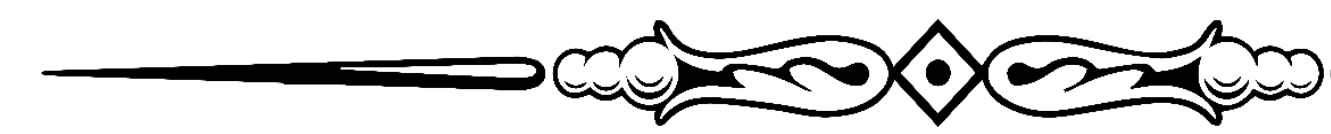

